\title{
PENGARUH FAKTOR FUNDAMENTAL DALAM PENENTUAN KEBIJAKAN PEMBAYARAN DIVIDEN PADA PERUSAHAAN PABRIKAN
}

\author{
Alia Ariesanti \\ Universitas Ahmad Dahlan Yogyakarta \\ e-mail : ariesanti_sutanto@yahoo.co.id
}

\begin{abstract}
ABSTRAK
The aim of this study is to analyze the effect of liquidity, profitability, solvability, and history of dividend-payment on dividend policy. This study focused on sample manufacturing firms, that shared dividend between 2007-2011 or not shared which listing in Indonesia Stock Exchange. To analyze the relationship, this study used logistic regression because the measurement of dependend variable is binary. This study found an empirical prove that history of dividen-payment impacted on dividend policy. The possibility of dividend-payment by company had history one year ahead dividendpayment greater 64 times than company that not paid. The another independend variables, that is liquidity, profitability, and solvability, not impacted on dividend policy. Signalling devidend theory provided the answer to explain this result study.
\end{abstract}

Keywords: dividend policy, financial ratio, history of dividend-payment, signalling dividend theory

\begin{abstract}
PENDAHULUAN
Setiap investor dihadapkan pada berbagai pilihan dalam menentukan proporsi dana atau sumber daya yang mereka miliki untuk membeli sejumlah saham saat ini dengan harapan memperoleh keuntungan di masa yang akan datang. Tujuan utama seorang investor menanamkan dana adalah untuk memperoleh pendapatan (return), dan return tersebut dapat berupa dividend yield (pendapatan dividen) maupun capital gain (pendapatan dari selisih harga jual saham terhadap harga belinya). Dalam kaitannya dengan pendapatan dividen, para investor umumnya menginginkan pembagian dividen. Alasan investor lebih menginginkan "pembagian deviden" dijelaskan dalam teori bird in the hand, bahwa pembagian melalui deviden memiliki resiko yang lebih kecil dibandingkan pembagian melalui capital gains.
\end{abstract}

Di sisi lain perusahaan dihadapkan dalam berbagai macam kebijakan internal antara lain berupa: perlunya menahan sebagian laba untuk re-investasi yang mungkin lebih menguntungkan, kebutuhan dana perusahaan, likuiditas perusahaan, sifat pemegang saham, atau target-target tertentu yang berhubungan dengan rasio pembayaran dividen serta faktor lain yang berhubungan dengan kebijakan dividen. Halhal internal semacam ini perlu dipertimbangkan ketika perusahaan akan membagikan dividen kepada investor. Sesuai dengan fungsi manajemen keuangan, umumnya tujuan pembagian dividen adalah untuk memaksimumkan kemakmuran pemegang saham, menunjukkan likuiditas perusahaan, pemenuhan kebutuhan para pemegang saham akan pendapatan riil, serta sebagai alat komunikasi antara manajer dan pemegang saham. 
Dengan demikian pembagian dividen memang sangat penting bagi suatu perusahaan untuk dapat menarik investor yang nantinya dapat membantu perusahaan menjalankan usahanya. Dalam penentuan pembagian dividen, perusahaan perlu mempertimbangkan berbagai faktor yang dapat mempengaruhi kebijakan dividen itu sendiri. Faktor yang mempengaruhi kebijakan dividen berasal dari faktor internal dan faktor eksternal (Prihantoro, 2003). Untuk faktor internal maupun eksternal perlu diperhatikan karena pembayaran dividen mempunyai kandungan informasi mengenai kondisi perusahaan saat ini maupun prospek perusahaan di masa mendatang. Faktor eksternal menyangkut peraturan pemerintah, inflasi dan stabilitas sosial politik. Sedangkan faktor internalnya meliputi, perputaran penjualan, tingkat keuntungan yang mampu direalisasikan perusahaan, stabilitas dividen, kebutuhan dana untuk membayar utang serta likuiditas perusahaan (Riyanto, 1998).

Likuiditas merupakan kemampuan keuangan dari suatu perusahaan untuk memenuhi kewajiban keuangan pada saat ditagih. Perusahaan yang mampu memenuhi kewajiban keuangannya pada saat ditagih berarti perusahaan tersebut dalam keadaan likuiditas yang baik. Sebaliknya jika perusahaan tidak mampu memenuhi kewajiban keuangannya pada saat ditagih maka perusahaan itu dalam keadaan tidak likuid. Likuid disini menunjukkan kemampuan perusahaan untuk menutup kewajiban jangka pendek dengan menggunakan aktiva lancarnya. Semakin tinggi likuditas suatu perusahaan maka semakin besar kemampuan perusahaan dalam membayar kewajibannya. Tingginya likuiditas menunjukkan semakin tinggi pula kemampuan perusahaan dalam membayar dividen.

Pembayaran dividen yang dilakukan oleh perusahaan selalu dikaitkan dengan kebijakan dividen yang diambil. Apabila perusahaan memilih untuk membagikan laba sebagai dividen, maka akan mengurangi laba yang ditahan dan selanjutnya akan mengurangi total sumber dana intern (internal financing). Sebaliknya jika perusahaan memilih untuk menahan laba yang diperoleh, maka kemampuan pembentukan dana intern akan semakin besar. Dengan demikian bagi perusahaan, kebijakan dividen sangat penting karena menyangkut tentang besar kecilnya laba yang akan dibagikan oleh perusahaan.

Dari sisi investor, apabila tujuan utama seorang investor ketika dia memutuskan melakukan investasi adalah untuk memperoleh return yang berupa dividen (dividend yield). Maka pihak perusahaan, dalam hal ini manajer merasa bahwa pemegang saham berhak atas bagian laba perusahaan melalui dividen (Lintner .1996 dalam Baker dan Powell (1999) dalam Apriani (2005). Oleh karena itu, manajemen berkewajiban membagikan laba yang diperoleh perusahaan kepada investor dalam bentuk dividen sebagai bentuk pertanggung-jawaban atas dana yang telah dipercayakan kepada manajemen. Namun apabila pihak perusahaan tidak membagikan dividen, maka investor merasa tidak ada penambahan kemakmuran secara langsung.

Kebijakan pembayaran dividen memiliki dua dampak yang berlawanan. Apabila laba perusahaan dibagikan sebagai dividen keseluruhan maka keputusan cadangan akan terabaikan, sebaliknya bila laba ditahan seluruhnya (tidak ada pembagian dividen) maka kepentingan pemegang saham terhadap uang kas juga terabaikan. Untuk menjaga kedua kepentingan tersebut manajer keuangan harus mengambil kebijakan dividen yang optimal. Semakin besar tingkat laba yang diperoleh, maka kemungkinan perusahaan untuk membayar dividen semakin besar. Semakin likuid kondisi perusahaan, maka semakin besar kemungkinan untuk membayar dividen.

Perusahaan yang membutuhkan dana untuk perluasan usaha maupun untuk kegiatan operasi dapat memperolehnya melalui utang. Sebelum perusahaan meminjam dana, harus sudah direncanakan terlebih dahulu kebutuhan 
dana untuk membayar kembali utang tersebut. Utang dapat dilunasi pada saat jatuh tempo dengan mengganti utang dengan utang baru. Alternatif lain adalah perusahaan harus menyediakan dana sendiri yang berasal dari keuntungan untuk melunasi utang. Suatu perusahaan akan memprioritaskan laba yang diperolehnya untuk membayar utang sedangkan sisanya akan dibagikan sebagai dividen. Sehingga semakin kecil utang perusahaan maka semakin besar kemungkinan perusahaan untuk membayar dividen.

Survei yang dilakukan oleh Farrelly et.al.(1985) dalam Apriani (2005) menunjukkan bahwa kebijakan dividen mempengaruhi nilai perusahaan dan terdapat tingkatan optimal pembayaran dividen. Pada praktiknya, sebagian besar perusahaan membayar dividen meskipun membayar dividen membutuhkan biaya. Sehingga manajemen berusaha selalu membayar dividen, terutama jika pada periode sebelumnya perusahan tidak membagi dividen.

Penelitian ini bertujuan untuk menganalisis faktor-faktor yang berpengaruh terhadap kebijakan dividen. Faktor-faktor yang dianalisis dalam penelitian ini adalah faktor likuiditas, profitabilitas, solvabilitas, dan riwayat pembayaran dividen.

\section{REVIEW LITERATUR DAN HIPOTESIS}

Dividen merupakan pembagian laba kepada pemegang saham berdasarkan banyaknya saham yang dimiliki. Pembagian laba ini akan mengurangi laba ditahan perusahaan, dan merupakan bentuk distribusi keuntungan kepada pemegang saham. Distribusi keuntungan ini adalah tujuan utama suatu bisnis, yaitu memaksimalkan kemakmuran bagi pemilik perusahaan.

Jenis dan besarnya dividen yang dibayarkan kepada pemegang saham ditentukan dalam Rapat Umum Pemegang Saham (RUPS).
Dividen yang dibayarkan tidak selalu sama mengenai besar dan periodenya, tergantung pada kondisi dan kebijakan manajemen perusahaan. Untuk jenis dividen dibagi menjadi beberapa jenis, yaitu:

1. Dividen kas

Jenis dividen yang dibagikan dalam bentuk uang tunai (kas). Jenis dividen ini merupakan yang paling umum dan diminati oleh investor.

2. Dividen Properti

Jenis dividen ini dibagikan dalam bentuk aset perusahaan seperti merchandise, real estate, investasi, dan lain-lain. Jenis dividen ini umumnya dibagikan oleh perusahaaan tambang yang selalu berpindah-pindah lokasi penambangannya.

3. Liquidating Dividend

Jenis dividen ini dibagikan dalam rangka mengembalikan sebagian investasi kepada pemegang saham. Jenis dividen ini merupakan satu-satunya jenis dividen yang membagikan dividen dengan mengurangi agio saham (paid in capital) perusahaan.

4. Dividen Saham

Dividen yang dibagikan dalam bentuk saham di perusahaan tersebut. Jenis dividen ini biasanya akan dipakai oleh perusahaan yang tidak mempunyai uang tunai yang cukup untuk membagikan dividen tetapi perusahaan tetap ingin membagikan dividen. Dividen saham dapat menggantikan dividen kas maupun sebagai dividen tambahan yang dibagikan kepada investor.

Dividen saham ini dalam pembayarannya dinyatakan dalam persentase dari jumlah saham yang beredar, dan investor akan memperoleh sebesar persentase jumlah saham yang dimiliki.

5. Scrip Dividend

Dividen yang dibagikan dalam bentuk notes payable (surat hutang). Jenis dividen ini sudah jarang dipakai saat ini. 
Miller dan Modigliani (1961) menyatakan bahwa dividen sifatnya adalah tidak relevan untuk menentukan nilai perusahaan. Jika pernyataan ini benar, maka tidak ada perusahaan yang akan membayar dividen. Kenyataannya, sampai saat ini masih banyak perusahaan yang membayar dividen bahkan meningkatkan nilai dividen. Ada beberapa penjelasan yang memberikan argumentasi alasan perusahaan membagikan dividen kepada pemegang saham, yaitu birdin-the hand, signalling, tax preference, dan keagenan.

\section{Penjelasan the bird-in-the-hand}

Penjelasan ini menyatakan bahwa investor lebih berharap menerima dividen daripada mengharapkan capital gain. Investor menyukai dividen sehingga akan menaikkan harga saham perusahaan jika perusahaan membayarkan dividen yang tinggi. Pembayaran dividen saat ini akan menurunkan ketidakpastian yang dihadapi pemegang saham, sehingga akan meningkatkan nilai sahak di bursa efek.

\section{Signaling}

Alasan lainnya yang mungkin untuk pembayaran dividen adalah pengunaan kebijakan dividen untuk mengkomunikasikan informasi mengenai prospek masa depan perusahaan bagi investor. Berdasarkan kandungan informasi dari dividen atau penjelasan signaling, pengumuman dividen kas menyampaikan informasi yang bernilai mengenai penilaian manajemen terhadap profitabilitas masa datang perusahaan.

Asimetri informasi memberi kesan bahwa manajer kantor pusat mempunyai informasi melebihi investor luar. Jika manajer mempunyai informasi yang tidak dipunyai oleh investor maka manajer dapat menggunakan perubahan dalam dividen sebagai carauntuk menunjukkan sinyal informasi dan kemudian menurunkan asimetri informasi. Kemudian investor akan menggunakan pengumuman dividen sebagai informasi untuk menilai harga saham perusahaan (Apriani, 2005).

\section{Tax-preference (preferensi tingkat pajak)}

Pendapatan dividen yang diterima pemegang saham akan dikenakan pajak dan dibayarkan pada saat dividen diterima, sedangkan pajak atas capital gain hanya dikenakan jika aset (saham) telah terjual. Perlakuan yang menguntungkan dari capital gains melebihi dividen akan mengarahkan investor untuk lebih memilih pembayaran dividen yang lebih rendah daripada yang lebih tinggi. Perbedaan tingkat pajak menyebabkan adanya preferensi investor terhadap salah satu kebijakan dividen. Investor dengan pajak tinggi akan menyukai saham dengan dividen rendah, begitu pula sebaliknya

\section{Toeri keagenan}

Teori ini diturunkan dari konflik kepentingan antara manajer kantor pusat (agen) dan pemegang saham luar (principal).Sebagai contoh, manajemen dapat mengkonsumsi penghasilan tambahan dari laba kantor pusat yang tidak didistribusikan dan menginvestasi dana yang ditahan secara suboptimal. Konflik ini mengarah ke biaya keagenan.Teori keagenan mengatakan bahwa mekanisme dividen menyediakan insentif bagi manajer untuk menurunkan biaya yang berkaitan dengan hubungan principal/agen.Satu cara untuk mengurangi biaya keagenan adalah meningkatkan dividen. Membayar dividen yang lebih besar menurunkan arus kas internal yang berkaitan dengan kebijakan manajemen dan memaksa perusahaan untuk mencari lebih banyak pendanaan eksternal.Jadi, pembayaran dividen dapat sebagai alat untuk memonitor dan mempertanggungjawabkan kinerja manajemen (Apriani, 2005).

Kebijakan pembayaran dividen merupakan keputusan penting dalam suatu perusahaan. Kebijakan ini akan melibatkan dua pihak yang mempunyai kepentingan berbeda, yaitu pemegang saham dan pihak manajemen. Dividen merupakan pembayaran kepada pemegang 
saham atas laba yang diperoleh perusahaan sehingga dapat meningkatkan kesejahteraan pemegang saham. Sedangkan dari pihak manajemen, pembagian dividen merupakan pengurangan laba ditahan, yang dapat digunakan sebagai sumber pendanaan internal, misalnya untuk pengembangan usaha, menjaga likuiditas perusahaan, ataupun untuk memenuhi kebutuhan operasional perusahaan.

Kebijakan pembayaran dividen merupakan kebijakan untuk mengalokasikan laba ditahan untuk dibagikan dalam bentuk dividen atau tidak dibagikan yang dapat digunakan sebagai sumber pendanaan internal. Manajemen memerlukan pertimbangan yang cermat untuk pengambilan keputusan pembayaran dividen. Ada beberapa faktor yang menjadi pertimbangan manajemen dalam pengambilan keputusan pembayaran dividen. Faktor-faktor yang dipertimbangkan manajemen adalah faktor likuiditas, profitabilitas, solvabilitas, dan riwayat pembayaran dividen.

\section{Pengaruh Likuiditas Terhadap Kebijakan Pembayaran Dividen}

Likuiditas perusahaan merupakan salah satu pertimbangan utama dalam banyak keputusan dividen. Likuiditas mengindikasikan kemampuan perusahaan untuk memenuhi kewajiban-kewajibannya pada saat jatuh tempo. Likuiditas sering diartikan sebagai tersedianya kas yang cukup. Perusahaan yang tumbuh dan menguntungkan bisa tidak likuid, karena dananya mungkin digunakan untuk membeli aktiva tetap dan sebagai modal kerja permanen. Umumnya pihak manajemen akan mempertahankan likuiditasnya untuk memberikan fleksibilitas dan perlindungan terhadap ketidakpastian, sehingga pihak manajemen tidak ingin mempertaruhkan resiko pada posisi ini dengan membayar dividen yang besar.

Laba ditahan biasanya diinvestasikan dalam bentuk aktiva yang diperlukan untuk menjalankan usaha, bukan disimpan dalam bentuk uang tunai. Oleh karena itu suatu perusahaan yang keuntungannya luar biasa mungkin saja tidak dapat membayar dividen karena keadaan likuiditasnya. Dalam situsai seperti itu mungkin perusahaan memutuskan untuk tidak membayar dividen dalam bentuk uang tunai atau bisa saja perusahaan memutuskan untuk tidak membayar dividen. Berdasar penjelasan tersebut, maka dapat dirumuskan hipotesis sebagai berikut:

\section{$\mathrm{Ha}_{1}$ : Faktor likuiditas berpengaruh terhadap kebijakan pembayaran dividen}

\section{Pengaruh Profitabilitas Terhadap Kebijakan Pembayaran Dividen}

Salah satu tujuan perusahaan adalah untuk mendapatkan laba yang sebesar-besarnya. Weston dan Brigham (1993) mendefinisikan profitabilitas sebagai hasil bersih dari berbagai kebijakan dan keputusan perusahaan yang mendatangkan manfaat bagi perusahaan berupa pendapatan atau laba. Pendapat lain juga dikatakan oleh Anthony et al. (1995) yang berpendapat bahwa profitabilitas merupakan selisih antara pendapatan yang diperoleh perusahaan dan biaya yang dikeluarkan oleh perusahaan dalam menjalankan aktivitasnya. Riyanto (1999) mengatakan bahwa profitabilitas merupakan hasil akhir dari sejumlah kebijaksanaan dan keputusan-keputusan perusahaan.

Dari ketiga pengertian tentang profitabilitasdapat diambil suatu pengertian bahwa profitabilitas adalah hasil usaha yang diperoleh perusahaan yang berupa selisih antara pendapatan dan biaya.Hasil tersebut merupakan hasil usaha yang didapatkan oleh perusahaan dari berbagai kebijakan dan keputusan yang telah direncanakan dan dilaksanakan.Rasio profitabilitas mengukur tingkat efektivitas manajemen perusahaan atas hasil yang dicapai perusahaan dalam melakukan penjualan dan investasi.

Profitabilitas merupakan hasil bersih dari berbagai kebijakan dan keputusan perusahaan 
yang akan mendatangkan manfaat bagi perusahaan berupa pendapatan atau laba. Menurut penelitian Lintner (1996) mengatakan bahwa pembagian dividen dipengaruhi oleh tingkat keuntungan (profitabilitas). Sedangkan menurut Jensen et.al. (1992) menyatakan laba yang lebih tinggi bisa meningkatkan kemungkinan dividen yang tinggi. Chen dan Steiner (1999) mengatakan semakin tinggi profitabilitas suatu perusahaan, maka earning yang diperoleh juga tinggi sehingga dapat diharapkan rasio dividen yang tinggi pula.

Kemampuan perusahaan dalam memperoleh laba merupakan indikator utama dari kemampuan perusahaan untuk membayar dividen, sehingga profitabilitas sebagai faktor penentu terpenting terhadap dividen (Lintner, 1996). Bukti empiris yang menghubungkan profitabilitas dengan dividen dilakukan oleh Brittain (1966) dalam penelitian Parthington (1989) menunjukkan bahwa profit sebagai pengganti variabel aliran kas secara signifikan berpengaruh terhadap dividen. Parthington (1989) menunjukkan bukti bahwa stabilitas dividen dan earning merupakan variabel yang penting yang dapat mempengaruhi preferensi investor untuk memperoleh dividen di masa yang akan datang. Berdasar penjelasan tersebut, maka dapat dirumuskan hipotesis sebagai berikut:

\section{$\mathrm{Ha}_{2}$ : Faktor profitabilitas berpengaruh terhadap kebijakan pembayaran dividen}

\section{Pengaruh Solvabilitas Terhadap Kebijakan Pembayaran Dividen}

Utang merupakan pembiayaan eksternal yang digunakan untuk membiayai kebutuhan perusahaan. Untuk penggunaan alokasi utang harus dipertimbangkan besarnya biaya tetap yang muncul, yaitu berupa bunga yang akan menyebabkan semakin meningkatnya leverage keuangan dan semakin tidak pastinya tingkat pengembalian bagi para pemegang saham: dividen (Dharmastuti, et. al., 2006).
Menurut Chen dan Steiner (1999), variabel risiko mempunyai hubungan negatif dan signifikan terhadap kebijakan dividen. Dengan tingginya risiko bisnis yang dihadapi oleh perusahaan akan diantisipasi dengan kebijakan pembayaran dividen yang rendah. Dividen yang rendah dapat digunakan digunakan untuk menghindari pemotongan dividen di masa mendatang sehingga pengalokasian sebagian keuntungan pada laba ditahan dapat digunakan untuk investasi lebih lanjut.

Melalui penjelasan balancing model of agency cost, Megginson (1997) dalam Mahadwartha(2002) menyatakan bahwa kebijakan utang mempengaruhi kebijakan dividen dengan hubungan yang negatif. Perusahaan dengan tingkat utang yang tinggi akan berusaha untuk mengurangi agency cost of debt-nya (mengurangi utang), sehingga untuk membiayai investasinya digunakan pendanaan dari aliran kas internal. Pemegang saham akan merelakan aliran kas internal yang sebelumnya dapat digunakan untuk pembayaran dividen dilakukan untuk membiayai investasi. Berdasar penjelasan tersebut, maka dapat dirumuskan hipotesis sebagai berikut:

\section{$\mathrm{Ha}_{3}$ : Faktor solvabilitas berpengaruh terhadap kebijakan pembayaran dividen}

\section{Pengaruh Riwayat Pembayaran Dividen Terhadap Kebijakan Pembayaran Dividen}

Penelitian yang dilakukan Asquith dan Mullins (1983) dalam Jogiyanto (2008) memberikan bukti empiris bahwa perusahaan yang membayar dividen pertama kalinya setelah 10 tahun tidak pernah membayar dividen, maka pembayaran dividen ini akan merupakan sesuatu kejutan dan akan berakibat reaksi yang kuat dari pasar. Ini berarti informasi pembayaran dividen mempunyai kandungan informasi yang langsung direspons oleh pelaku pasar modal.

Teori keagenan memberikan indikasi bahwa mekanisme dividen menyediakan insentif bagi manajer untuk menurunkan biaya yang 
berkaitan dengan hubungan prinsipal/agen. Satu cara untuk mengurangi biaya keagenan adalah meningkatkan dividen. Perusahaan yang membayar dividen drngan jumlah lebih besar akan menurunkan arus kas internal yang berkaitan dengan kebijakan manajemen dan memaksa perusahaan untuk mencari lebih banyak pendanaan eksternal (Apriani, 2005). Jadi, pembayaran dividen dapat digunakan sebagai alat untuk memonitor dan mempertanggungjawabkan kinerja manajemen. Berdasar penjelasan tersebut, maka dapat dirumuskan hipotesis sebagai berikut:

\section{$\mathrm{Ha}_{4}$ : Faktor riwayat pembayaran dividen berpengaruh terhadap kebijakan dividen}

\section{METODE PENELITIAN}

\section{Obyek Penelitian Dan Sampel}

Obyek penelitian ini adalah perusahaan yang membagi dividen yang terdaftar di Bursa Efek Jakarta. Obyek amatan adalah laporan keuangan perusahaan pabrikan yang terdaftar di Bursa Efek Jakarta yang mengumumkan dividen tunai antara tahun 2007-2010.

Sampel penelitian ini adalah perusahaan pabrikan yang terdaftar di Bursa Efek Jakarta pada tahun 2007-2011, yang memenuhi kriteria:

1. Perusahaan tersebut membagi dividen tunai antara tahun 2007-2010;

2. Perusahaanyangtidakmembagidividendipilih secara random. Jumlah sampel perusahaan yang tidak membagi dividen ditentukan berdasar banyaknya data variabel dependen yang bernilai 1 . Hal ini dilakukan agar data variabel dependen jumlahnya seimbang atau mendekati seimbang. Keseimbangan banyaknya data variabel dependen antara yang bernilai 1 dan 0 diperlukan karena pada data variabel dependen bersifat binary.
3. Perusahaan mempunyai akhir tahun fiskal pada bulan Desember, agar laporan keuangan parsial tidak termasuk dalam penelitian ini.

\section{Variabel Penelitian}

Variabel dependen dalam penelitian ini adalah kebijakan pembagian dividen tunai. Pengukuran variabel ini menggunakan dummy. Perusahaan yang membagi dividen tunai pada suatu tahun diberi kode 1, sedangkan perusahaan yang tidak membagi dividen pada suatu tahun diberi kode 0 .

Variabel independen penelitian ini adalah rasio keuangan likuiditas, profitabilitas, solvabilitas dan riwayat pembayaran dividen dimasa mendatang. Pengukuran variabel independen adalah sebagai berikut:

1. Rasio likuiditas

Rasio likuiditas menunjukkan kemampuan perusahaan untuk memenuhi kewajiban lancar dengan menggunakan aktiva lancarnya.Rasio ini diukur dengan menggunakan current ratio.Penghitungan rasio ini dengan rumus:

$$
\mathrm{CR}=\frac{\text { Aktiva Lancar }}{\text { Utang Lancar }}
$$

2. Rasio profitabilitas

Rasio profitabilitas menunjukkan kemampuan perusahaan untuk menghasilkan laba. Rasio ini diukur dengan menggunakan ROA (Return on Assets). Penghitungan rasio ini dengan rumus:

$$
\mathrm{ROA}=\frac{\text { Laba Bersih Setelah Pajak }}{\text { Total Aset }}
$$

3. Rasio solvabilitas

Rasio solvabilitas menunjukkan kemampuan perusahaan untuk memenuhi kewajibannya. Rasio ini juga dapat menunjukkan komposisi pembiyaan perusahaan yang didanai dari kreditor dan yang didanai oleh pemilik 
perusahaan. Rasio ini diukur dengan debt-toequity. Penghitungan rasio ini dengan rumus:

$$
\text { DER }=\frac{\text { Total Utang }}{\text { Total Ekuitas }}
$$

4. Riwayat pembayaran dividen

Variabel inimenunjukkan riwayat pembayaran dividen dimasa lalu.Variabel ini diukur dengan dummy. Perusahaan yang membayar dividen pada tahun sebelumnya diberi kode 1 , sedangkan perusahaan yang tidak membayar dividen satu tahun sebelumnya diberi kode 0 .

\section{Pengujian Hipotesis}

Dalam penelitian ini analisis data yang digunakan untuk menguji hipotesis adalah uji regresi logistik karena memiliki variabel dependen yang diukur secara nominal berupa data dummy. Regresi logistik digunakan untuk melihat atau mengetahui variabel independen berpengaruh terhadap variabel dependen. Selain itu regresi logistik juga memiliki beberapa kelebihan. Kelebihan metoda regresi logistik adalah lebih fleksibel dibandingkan teknik lain, yaitu (Kuncoro, 2004: 217):

a. Regresi logistik tidak memiliki asumsi normalitas atas variabel bebas yang digunakan dalam model. Artinya, variabel penjelas tidak harus memiliki distribusi normal, linier, maupun memiliki varian yang sama dalam setiap grup.

b. Variabel bebas dalam regresi logistik bisa campuran dari variabel kontinyu, diskrit, dan dikotomus.

c. Regresi logistik amat bermanfaat digunakan apabila distribusi respon atas variabel terikat diharapkan nonlinear dengan satu atau lebih variabel bebas.

Model regresi logistik yang akan digunakan dalam penelitian ini adalah:

KDev $=\beta_{0}+\beta_{1}$ Lik $+\beta_{2}$ Profit $+\beta_{3}$ Sol + $\beta_{4}$ Riw $+\varepsilon$
Keterangan:

Kdev $=$ Kebijakan Dividen, diukur dengan variabel dummy, 1 untuk perusahaan yang membagi dividen dan 0 untuk perusahaan tidak membagi dividen.

Lik = Variabel likuiditas, diukur dengan current ratio

Profit $=$ Variabel profitabilitas, diukur dengan return on equity

Sol = Variabel solvabilitas, diukur dengan debt to equity ratio

Riw = Riwayat pembayaran dividen

$\varepsilon \quad=$ Error term

HASIL PENELITIAN DAN PEMBAHASAN

\section{Deskripsi Sampel Penelitian}

Antara tahun 2008-2011, ada 69 perusahaan pabrikan yang membagikan dividen tunai. Dari 69 perusahaan tersebut tidak seluruhnya membagi dividen pada tahun 20072011 secara berturut-turut. Untuk deskripsi jumlah perusahaan yang membayar dividen dapat dilihat pada tabell.

Pada tabel 1 dapat terlihat bahwa dari 69 perusahaan yang membayar dividen antara tahun 2008-2011, dengan rincian 217 data perusahaan yang membayar dividen dan 58 data perusahaan yang tidak membayar dividen. Agar jumlah tersebut imbang atau mendekati imbang, maka diperlukan tambahan data dari perusahaan yang tidak membayar dividen antara tahun 2007-2010. Diperlukan 40 perusahaan lagi (159 data, yaitu 40 perusahaan selama 4 tahun) untuk melengkapi data penelitian ini.

Tabel.1

Deskripsi Jumlah Perusahaan Pembayar Dividen

\begin{tabular}{|c|c|c|}
\hline Tahun & $\begin{array}{c}\text { Jumlah data pembayar } \\
\text { dividen }\end{array}$ & $\begin{array}{c}\text { Jumlah data } \\
\text { tidak membayar } \\
\text { dividen }\end{array}$ \\
\hline 2007 & 54 & 15 \\
\hline 2008 & 56 & 13 \\
\hline 2009 & 51 & 18 \\
\hline 2010 & 56 & 12 \\
\hline Jumlah & 217 & 58 \\
\hline
\end{tabular}




\section{Analisis Deskriptif}

Tabel 2 menjelaskan tentang variabel yang berupa rasio keuangan yang dibahas pada penelitian ini. Rata-rata likuiditas untuk seluruh perusahaan adalah sebesar 390,95. Ini berarti rata-rata likuiditas seluruh perusahaan sampel selama 4 tahun, yang diukur dengan menggunakan current ratio menunjukkan aktiva lancar besarnya 3,91 kali dari utang lancarnya. Dengan kata lain, rata-rata seluruh perusahaan mampu membayar seluruh kewajiban lancarnya dengan menggunakan aktiva lancarnya.

Tabel 2

\section{Rata-Rata Nilai Setiap Rasio Keuangan}

\begin{tabular}{|l|c|c|c|}
\hline Rasio & $\begin{array}{c}\text { Seluruh } \\
\text { Perusahaan }\end{array}$ & $\begin{array}{c}\text { Perusahaan yang } \\
\text { pembayar dividen }\end{array}$ & $\begin{array}{c}\text { Perusahaan } \\
\text { yang tidak } \\
\text { membayar } \\
\text { dividen }\end{array}$ \\
\hline CR & 390,95 & 348,26 & 434,26 \\
\hline ROA & $-12,24$ & 15,71 & $-40,57$ \\
\hline DER & 2,22 & 1,12 & 3,33 \\
\hline
\end{tabular}

Sumber: data diolah

Untuk likuiditas perusahaan yang membayar dividen antara tahun 2008-2011 menunjukkan rata-rata sebesar 348,26. Ini berarti rata-rata likuiditas perusahaan pembayar dividen, yang diukur dengan menggunakan current ratio menunjukkan aktiva lancar besarnya 3,48 kali dari utang lancarnya. Dengan kata lain, rata-rata seluruh perusahaan mampu membayar seluruh kewajiban lancarnya dengan menggunakan aktiva lancarnya. Sedangkan untuk likuiditas perusahaan yang tidak membayar dividen menunjukkan ratarata sebesar 434,24. Ini berarti rata-rata likuiditas perusahaan yang tidak membayar dividen, yang diukur dengan menggunakan current ratio menunjukkan aktiva lancar besarnya 4,34 kali dari utang lancarnya. Dengan kata lain, rata-rata seluruh perusahaan mampu membayar seluruh kewajiban lancarnya dengan menggunakan aktiva lancarnya
Rata-rata rasio profitabilitas, yang diukur dengan rasio ROA (return on assets), seluruh perusahaan sampel adalah sebesar $-12,24$. Ini berarti rata-rata selama 4 tahun seluruh perusahaan mengalami kerugian sebesar $12,24 \%$. Untuk perusahaan pembayar dividen antara tahun 2008-2011 menunjukkan rata-rata profitabilitas sebesar 15,71 . Ini berarti rata-rata selama 4 tahun perusahaan pembayar dividen atara tahun 2008-2011 menghasilkan laba bersih setelah pajak dari total aset yang dimiliki sebesar $15,71 \%$. Sedangkan untuk perusahaan yang tidak membayar dividen rata-rata profitabilitasnya sebesar -40,57. Ini berarti rata-rata selama 4 tahun perusahaan yang tidak membayar dividen mengalami kerugian sebesar 40,57\%.

Rata-rata solvabilitas, yang diukur menggunakan rasio DER (debt to equity ratio) untuk seluruh perusahaan adalah sebesar 2,22. Ini berarti rata-rata seluruh perusahaan sampel selama 4 tahun besarnya total utang 2,22 kalinya dari ekuitas yang dimiliki. Artinya, perusahaan lebih banyak menggunakan utang dibandingkan ekuitas untuk mendanai total aktiva perusahaan. Untuk perusahaan pembayar dividen antara tahun 2008-2011, rata-rata solvabilitasnya adalah sebesar 1,12. Ini berarti rata-rata perusahaan pembayar dividen besarnya total utang 1,12 kalinya dari ekuitas yang dimiliki. Artinya untuk perusahaan pembayar dividen sumber pendanaan total aktiva perusahaan antara utang dengan ekuitasnya seimbang. Sedangkan untuk perusahaan yang tidak membayar dividen, ratarata solvabilitasnya sebesar 3,33 . Ini berarti ratarata perusahaan yang tidak membayar dividen, besar total utang 3,33 kalinya dari ekuitas yang dimiliki.

\section{Pengujian Hipotesis}

Untuk menguji hipotesis, penelitian ini menggunakan alat uji regresi logistik, karena variabel depedennya berupa data dummy. Regresi logistik ini digunakan untuk menjawab hipotesis 
adanya pengaruh faktor likuiditas, profitabilitas, solvabilitas dan riwayat pembayaran dividen terhadap kebijakan pembayaran dividen tunai.

1. Uji koefisien determinasi.

Dalam analisis regresi logistik, untuk melihat koefisien determinasi $\left(\mathrm{R}^{2}\right)$ dengan menggunakan nilai pseudo $\mathrm{R}^{2}$ untuk mengukur goodness of fit. Untuk menginterpetasikan pengujian koefisien determinasi digunakan pengukuran Mc Fadden $\mathrm{R}^{2}$ yang biasa ditulis dengan $\mathrm{R}^{2}{ }_{\text {MCF }}$. Berdasar hasil pengujian regresi logistik, diketahui bahwa nilai $\mathrm{R}_{\mathrm{MCF}}^{2}$ adalah sebesar 0,5051 atau $50,51 \%$ (lampiran 3). Artinya bahwa rasio likuiditas, profitabilitas, solvabilitas dan riwayat pembayaran dividen yang digunakan dalam model dapat menjelaskan kebijakan pembayaran dividen sebesar 50,51\%, sedangkan 49,49\% sisanya dijelaskan variabel lain yang tidak dimasukkan dalam model ini.

Selain McFadden $\mathrm{R}^{2}$, pada regresi logistik untuk mengukur goodness of fit adalah count $\mathrm{R}^{2}$. Berdasarkan hasil penghitungan diketahui bahwa 350 data dari 435 (lampiran 3) data sesuai dengan prediksi dan 85 data tidak sesuai dengan prediksi. Nilai count $\mathrm{R}^{2}$ adalah sebesar 0,8051 atau $80,51 \%$. Karena nilai count $\mathrm{R}^{2}$ diatas 0,5 atau $50 \%$, berarti cukup banyak jumlah estimasi yang sesuai dengan prediksi.

2. Rasio Likelihood

Rasio likelihood dalam regresi logistik menggunakan kriteria yang sama dalam penggunaan uji-F dalam regresi linier, yang juga didasarkan nilai probabilitas (p-value) (Hair, 2006). Rasio ini digunakan untuk mengetahui adanya pengaruh minimal salah satu dari variabel independen yang mempengaruhi variabel dependen. Untuk melihat hasil pengujian ini dilakukan dengan melihat nilai Chi Square.

Berdasar hasil pengujian menunjukkan bahwa nilai LR statisik sebesar 304,60 dengan nilai probabilita LR statistik 0,00 yang berarti lebih kecil dari 0,05 (lampiran 3). Ini berarti faktor likuiditas, profitabilitas, solvabilitas, dan riwayat pembayaran dividen secara bersama-sama dapat menjelaskan model, yang berarti minimal salah satu dari variabel independen yang dibahas dalam model penelitian ini berpengaruh terhadap kebijakan pembayaran dividen.

3. Uji signifikansi koefisien

Uji signifikansi koefisien digunakan untuk menguji hipotesis. Hasil pengujian yang telah dilakukan tampak pada tabel 3.

Tabel 3

Hasil Uji Signifikansi Koefisen

\begin{tabular}{|l|r|r|l|}
\hline \multicolumn{1}{|c|}{ Rasio } & \multicolumn{1}{c|}{$\begin{array}{c}\text { Nilai Z } \\
\text { statistik }\end{array}$} & \multicolumn{1}{c|}{ Signifikansi } & Keputusan \\
\hline Likuiditas & $-1,00$ & 0,32 & $\mathrm{Ha}_{1}$ ditolak \\
\hline Profitabilitas & 0,31 & 0,75 & $\mathrm{Ha}_{2}$ ditolak \\
\hline Solvabilitas & $-1,35$ & 0,18 & $\mathrm{Ha}_{3}$ ditolak \\
\hline $\begin{array}{l}\text { Riwayat } \\
\text { pembayaran } \\
\text { dividen }\end{array}$ & 13,46 & 0,00 & $\mathrm{Ha}_{4}$ diterima \\
\hline
\end{tabular}

Sumber: data diolah

\section{Pembahasan}

Berdasarkan hasil pengujian regresi, variabel yang berpengaruh terhadap kebijakan pembayaran dividen adalah riwayat pembayaran dividen. Perusahaan yang satu tahun sebelumnya telah membayar dividen lebih besar kemungkinannya untuk membayar dividen pada tahun berjalan. Nilai koefisien untuk variabel riwayat pembayaran dividen adalah sebesar 4,16 (lampiran 2) sehingga nilai rasio odds sebesar 64,07 (diperoleh dari e 4,16). Ini berarti bahwa perusahaan yang membayar dividen pada tahun sebelumnya kemungkinan lebih besar 64,07 kali dibandingkan perusahaan yang tidak membayar dividen pada tahun sebelumnya untuk membayar dividen pada tahun berjalan.

Sedangkan variabel lain yang dianalisis dalam model penelitian ini, yaitu likuiditas, profitabilitas, solvabilitas ternyata tidak 
berpengaruh terhadap kebijkan pembayaran dividen. Ini berarti manajemen dalam membuat keputusan pembagian dividen, yaitu membagi dividen atau tidak membagi dividen, tidak melihat kondisi keuangannnya. Mereka tidak mempertimbangkan aspek ketersediaan aktiva lancar, kondisi kemampuan menghasilkan laba, ataupun besarnya utang yang mereka miliki. Hasil penelitian ini tidak sejalan dengan penelitian Prihantoro (2003) yang menyatakan bahwa posisi kas dan rasio utang dengan modal berpengaruh signifikan terhadap dividen payout ratio.

Hasil penelitian ini berarti memberikan bukti empiris bahwa perusahaan berusaha untuk selalu konsisten membayarkan dividen, karena dividen yang dibagikan kepada pemegang saham mempunyai kandungan informasi. Dividen yang dibagikan memberikan sinyal mengenai kondisi perusahaan (signalling theory). Umumnya, perusahaan enggan memotong dividen karena pengurangan dividen dianggap sebagai sinyal jelek oleh investor. Perusahaan yang memotong dividen akan dianggap mengalami kesulitan keuangan, sehingga perlu mendapatkan tambahan dana dengan memotong dividen (Jogiyanto, 2008). Perusahaan tidak ingin informasi ini diterima oleh pasar modal karena akan menurunkan nilai perusahaan. Akibatnya, harga saham perusahaan akan mengalami penurunan karena dianggap perusahaan sedang mengalami kesulitan keuangan.

\section{KESIMPULAN DAN SARAN}

\section{Simpulan}

Berdasar hasil pengujian logistik dapat diketahui bahwa bahwa rasio likuiditas, profitabilitas, solvabilitas dan riwayat pembayaran dividen yang digunakan dalam model dapat menjelaskan kebijakan pembayaran dividen sebesar 50,51\%, sedangkan 49,49\% sisanya dijelaskan variabel lain yang tidak dimasukkan dalam model ini. Sedangkan nilai count $\mathrm{R}^{2}$ adalah sebesar 0,8051 atau $80,51 \%$ yang berarti cukup banyak jumlah estimasi yang sesuai dengan prediksi.

Berdasar hasil pengujian rasio likelihood menunjukkan bahwa nilai LR statisik sebesar 304,60 dengan nilai probabilita LR statistik 0,00 . Ini berarti faktor likuiditas, profitabilitas, solvabilitas, dan riwayat pembayaran dividen secara bersama-sama dapat menjelaskan model, yang berarti minimal salah satu dari variabel independen yang dibahas dalam model penelitian ini berpengaruh terhadap kebijakan pembayaran dividen.

Berdasar hasil uji signifikansi koefisien, penelitian ini memberikan bukti empiris bahwa faktor riwayat pembayaran dividen berpengaruh terhadap kebijakan pembayaran dividen. Perusahaan yang satu tahun sebelumnya telah membayar dividen lebih besar kemungkinannya untuk membayar dividen pada tahun berjalan. Kemungkinan pembayaran dividen pada tahun berjalan oleh perusahaan yang satu tahun sebelumnya telah membayar dividen 64,07 kali lebih besar dibandingkan perusahaan yang tidak membayar dividen pada tahun sebelumnya.

$$
\text { Sedangkan variabel likuiditas, }
$$
profitabilitas, solvabilitas tidak berpengaruh terhadap kebijkan pembayaran dividen. Ini berarti manajemen dalam membuat keputusan pembagian dividen, yaitu membagi dividen atau tidak membagi dividen, tidak melihat kondisi keuangannnya. Mereka tidak mempertimbangkan aspek ketersediaan aktiva lancar, kondisi kemampuan menghasilkan laba, ataupun besarnya utang yang mereka miliki.

Hasil penelitian ini berarti memberikan bukti empiris bahwa perusahaan berusaha untuk selalu konsisten membayarkan dividen, karena dividen yang dibagikan kepada pemegang saham mempunyai kandungan informasi. Dividen yang dibagikan memberikan sinyal mengenai kondisi perusahaan (signalling theory). Perusahaan 
yang konsisten membayarkan dividennya menunjukkan likuiditas perusahaan dalam keadaan stabil (Jogiyanto, 2008).

\section{Saran Penelitian Selanjutnya}

Untuk penelitian selanjutnya, sebaiknya mempertimbangkan hal-hal berikut ini:

1. Memperpanjang tahun amatan, sehingga hasilnya lebih dapat digeneralisasi dan lebih kuat (robust) dan juga dapat dilihat riwayat pembayaran dividen lebih dari 1 tahun sebelumnya;

2. Objek penelitian dapat memilih selain perusahaan pabrikan;

3. Perlu dianalisis kondisi stabilitas keuangan perusahaan setiap tahunnya, sehingga dapat dilihat kondisi stabilitas keuangan perusahaan secara lebih detail.

\section{DAFTAR PUSTAKA}

Anthony, Robert N., John Dearden, dan Norton M. Bedford. Management Control System. Edisi 8. Homewood, Ill: Irwin

Apriani, Lisia. 2005. Reaksi Pasar Terhadap Pengumuman Kenaikan/Penurunan Dividen (Studi Empiris Pada Perusahaan Utilitas Publik Dan Perusahaan Dalam Industri Tidak Diregulasi). Dipublikasikan di Seminar Nasional Akuntansi VIII.

Chen, Carl R dan Steiner, Thomas L. 1999.

Managerial Ownership dan Agency Conflict: A Nonlinier Simultaneous Equation Analysis of Managerial Ownership, Risk Taking, Debt Policy, and Dividend Policy. The Financial Review. Volume 34

Dharmastuti, CH. Fara, Katarina Stella, dan Eviyani. 2006. Analisis Keterkaitan Secara Simultan antara Kebijakan Dividen dan Kebijakan Hutang pada Perusahaan yang Terdaftar di Bursa
Efek Jakarta Periode Tahun 2000-2002. Jurnal Business and Economics. Volume 11, Nomor 1

Hair, Joseph F. 2006.Multivariate Data Analysis. Sixth Edition. New Jersey: Prentice Hall.

Jensen, G, D. Solberg dan T. Zorn. 1992. Simultaneous determination of insider ownership, debt and dividen policies. Journal of Financial and Quantitative Analysis. Vol. 27 (2)

Jogiyanto, H.M. 2008. Teori Portofolio dan Analisis Investasi.Edisi Kelima. Yogyakarta: BPFE

Mahadwartha, PutuAnom. 2002. Interdependensi Antara Kebijakan Leverage dengan Kebijakan Dividen: Perspektif Teori Keagenan.Jurnal Riset Akuntansi, Manajemen dan Ekonomi 2 No.2,

Miller, M.H, dan F. Modigliani. 1961. Dividend Policy, Growth and the Valuation of Shares. Journal of Business, Vol. 34, 235-64

Kuncoro, Mudrajad. 2004. Metoda Kuantitatif. Edisi Kedua. Yogyakarta: BPFE UGM

Lintner, John. 1996. Distribution of Income of Corporations Among Dividend, Retained Earning and Taxes. The American Economics Review No. 46

Partington, Graham. 1989. Variables Influencing Dividend Policy in Australia: Survey Results. Journal of Business Finance and Accounting, Volume 16, hal. 165182

Prihantoro. 2003. Estimasi Pengaruh Dividend Payout Ratio pada Perusahaan Publik di Indonesia. Jurnal Ekonomi dan Bisnis. Nomor 1 Jilid 8.

Riyanto, Bambang. 1998. Dasar-Dasar Pembelanjaan Perusahaan. Yogyakarta: BPFE UGM.

Weston, J. Fred dan Eugene F. Brigham. 1999. Dasar-Dasar Manajemen Keuangan. Jakarta: Erlangga 